\title{
Research on Financial Consumer Protection
}

\author{
Haiyan Zhou \\ Fuzhou University of International Studies and Trade, Fuzhou, China
}

Keywords: finance; consumers; protection

\begin{abstract}
Financial consumption has gradually entered people's daily life. But financial consumers are often at a disadvantage due to the professionalism and complexity of financial institutions and the greed and shortsightedness of financial institutions. Financial consumers often suffer from unfair treatment when interest disputes occur between financial institutions and financial consumers. This concerns not only individual interests, but also the confidence of financial consumers in financial trading markets, thus further affecting the stability of financial markets. With the increase and complication of financial transaction relationship, new financial products have emerged endlessly in recent years, financial consumers' rights have been infringed but there are no complaints. Therefore, the protection of legitimate rights of financial consumers began to be gradually concerned.
\end{abstract}

\section{Introduction}

First of all, from the legal system, the most well-known consumer protection laws and regulations in China is only "consumer rights and interests protection law." However, the law only protects consumers in general sense and there is no effective regulation on the rights and interests of consumers in the financial field. Therefore, there are few laws and regulations focusing on the protection of financial consumers in our country, and there is a lack of laws and regulations especially for financial consumers. Secondly, from the perspective of the establishment of regulatory agencies, China also lacks specialized institutions for the protection of financial consumers. At present, China's financial regulators mainly include the central bank, the Securities Regulatory Commission, the Banking and Insurance Regulatory Commission and other institutions, which normally protect financial consumers in their respective fields. Finally, from the point of view of financial education, the loss of financial consumers' rights and interests has been concerned by the public in recent years due to the lack of financial knowledge of financial consumers. Because financial consumers lack relevant financial knowledge and financial consumers are always in a weak position relative to financial institutions, once financial consumers' rights and interests are damaged, it will be difficult to obtain appropriate relief. Although after the financial crisis, the awareness of safeguarding the rights of financial consumers gradually strengthened. But from the current stage of our country, there is not a series of financial consumer education system.

\section{Problems of Financial Consumer Protection in China}

With the rapid development of financial market, the proportion of financial investment in household expenditure is rising gradually. The following financial contradictions, disputes and litigation are also increasing. The main reason is still in the financial consumer protection there are some shortcomings. They are as follows.

\subsection{Deficiencies in existing legislation}

Compared with the huge financial transactions and financial consumers, the existing legal system of financial consumer protection in our country has only played a weak role in protection. The current law is divided into three levels: the first is the early protection of consumer rights and interests, but it only provides for the protection of general consumer rights and interests not the special protection of financial consumers. Secondly, some financial industry laws such as the "Commercial Bank Law" and the "Securities Act" and so on. Thirdly, the central bank, the Securities 
Regulatory Commission and other departments to formulate departmental regulations. However, there are many problems in these laws: firstly, the present law lacks professionalism and is not operable. Secondly, there is no special regulation for financial consumers. Thirdly, there are overlaps and omissions in the relevant regulations of various regulatory bodies.

\subsection{Unclear regulatory functions}

The financial supervision organs are restricted by separate legislation when they perform their supervisory duties. They are unable to give full play to their supervisory functions. The central bank, consumer associations and other supervisory agencies do not have professional oversight of financial consumer rights and interests. Although they are all involved, these institutions have overlapping functions and unclear powers. Consumers' associations at all levels are committed to the protection of consumers' consumption of non-financial products. For the protection of financial consumers, the respective functions and responsibilities of the regulators are not clear.

\subsection{Lack of effective relief mechanisms of financial consumer protection}

China has not established an effective conflict and dispute resolution mechanism for financial consumers. Financial institutions and regulators lack supervision, coordination and handling of consumer complaints and disputes, and do not fully establish clear and transparent mechanisms to facilitate rapid communication and dispute resolution with consumers. Laws and regulations are minimal in handling disputes. At present, the only regulations are: the Securities Regulatory Commission has issued provisional regulations, requiring securities companies to set up special departments to handle complaints and other matters arising from investors, and to do a good job in resolving financial conflicts and disputes. In order to implement this provision, the specific implementation measures are formulated, which stipulate that there should be a special department to deal with customer complaints and contradictions, record the overall situation, and report customer complaints and handling results as required.

\section{Countermeasures of Protecting the Rights and Interests of Financial Consumers in China}

\subsection{Improve the financial consumer protection system}

China has a huge financial consumer group, but the government has not formulated a matching financial consumer protection law. Some basic legislation has not reached the level of protection of financial consumers' rights and interests, so it is very necessary to improve the relevant legal protection system of our country. The financial industry of our country is still in the stage of rapid development, and the financial products are constantly changing. Therefore, the protection of financial consumers in our country must first improve the regulations and clarify the responsibilities of the supervision department. Only in this way can we ensure the protection of financial consumers' rights and interests, and the financial market can develop steadily.

\subsubsection{Amendment and improvement of regulations on the protection of financial consumers' rights and interests}

Financial consumers are defined in the regulations, and their rights and obligations are clearly defined, so that financial consumers can be supported under the protection of existing laws and regulations. The overlapping legal issues and rights and interests protection issues in various legislations such as the "Banking Law" and the "Securities Law" are appropriately amended so that the original scattered laws and legislation can be combined into a complete and systematic legal system. The principle of moderate protection can be applied to the weak financial consumers, so that the rights of consumers can be realized.

\subsubsection{Enhancement of information disclosure systems}

Modern financial transactions are convenient, such as online banking, mobile banking and other technologies have been widely used, so most financial consumers can not accurately and comprehensively understand financial institutions and financial products information. Asymmetric information between the two sides is easy to produce a variety of disputes. In the field of securities, the relevant laws and regulations have been established in the securities law of our country, and the 
specific contents, time and methods of securities disclosure have been clearly stipulated. So the development of securities in China is relatively stable. Therefore, it is necessary to expand and deepen the information disclosure system. For example, the content of information disclosure can deepen and expand the scope, the way of information disclosure is diversified, the time of information disclosure is grasped and the subject of information disclosure is expanded. Strengthening the information disclosure system can enable financial regulatory institutions to effectively supervise financial institutions and protect the related rights and interests of financial consumers.

\subsubsection{Strengthen information security protection for financial consumers}

To protect and maintain the personal information of financial consumers is a prerequisite for the confidence of consumers in financial institutions, so we must strengthen consumer information security and privacy protection. Firstly, financial consumers usually default that financial institutions will not disclose their personal information, so that they do not need to tell financial institutions to fulfil this obligation, resulting in the disclosure of their personal information. Therefore, to protect the information security of financial consumers, financial institutions must explicitly indicate whether consumers need to keep their private personal information confidential. Secondly, it is necessary to specify the procedure and conditions for the state organs to carry out the task of tracing crimes and to obtain the consumer's personal information directly.

\subsection{Enhancement of national financial education}

\subsubsection{Financial institutions should concrete the function of information consultation}

China's financial consumers have a large group, but generally lack of financial expertise. Therefore, financial institutions should provide professional and detailed information and establishment when consumers cannot accurately understand the specific conditions of products and services. If this is to be done, it is necessary to improve the knowledge structure of financial practitioners to enable them to promote financial products professionally and to better serve consumers.

\subsubsection{Holistic strengthening of consumer awareness and financial knowledge}

Financial education activities must be carried out among the masses. Experts should be taught on the spot, and relevant knowledge of finance should be widely disseminated, so that consumers can understand the risks of investment and enhance their awareness of investment risks. So that financial consumers can set up the correct concept of investment and participation in financial consumption, make financial activities more rational, and finally promote the formation of a more healthy and harmonious financial market.

\section{Conclusions}

Financial consumers are important participants in financial markets, and financial institutions cannot survive or develop without financial consumers. Protecting the rights and interests of financial consumers can build the confidence of the whole society to the financial industry, but also can lay a good foundation for the stable development of the financial industry and the promotion of high competitiveness. Therefore, the protection of the rights and interests of financial consumers is not only related to individual interests, but also affects economic security and social stability. It is of great significance to carry out this study for the stable and sustainable development of finance and economy.

\section{References}

[1] Xu Yuanqian. An empirical study on the Protection of Financial consumers' Rights and interests under the Internet: a case study of P2P [J]. Industrial Economic Review, 2016 (03).

[2] Xu Yaping. The latest Development of the Financial Complaints Commissioner system in Britain and its Enlightenment [J]. Zhejiang Finance, 2016 (02). 
[3] Luo Jingyuan, Analysis of the impact of Internet Finance on Consumer Protection and system Design [J]. China Development Watch. 2015 (01)

[4] Yang Dong. On the definition of Financial Consumer [J]. A jurist, 2014 (05).

[5] Pensward. Legal Protection of the Rights and interests of Internet Financial consumers [J]. Consumer economy, 2014 (05).

[6] Zhang Yuming, Wang Hongsheng. A study on the characteristics and operational Mechanism of Internet Finance from the Perspective of complex Adaptive Systems [J]. Journal of Shandong University (philosophy and Social Sciences Edition), 2014 (05).

[7] Shi Yude, Shang Fei Peng. Current situation and Countermeasures of Internet financial consumer protection in China [J]. North China finance, 2014 (04). 